\title{
EMMANUEL-JOSEPH Sieyès, O SĄDZIE KONSTYTUCYJNYM: TEZY PROJEKTU USTAWY PRZEDSTAWIONEGO PRZEZ EMMANUEla-Josepha SIEYÈsa PODCZAS ObRAD KonWENCJI W DNIU 18 THERMIDORA ROKU III
}

Krótki w formie, ale za to niezwykle obszerny w swojej treści, tekst „O sadzie konstytucyjnym" autorstwa Emmanuela-Josepha Sieyèsa pochodzi z drugiego okresu twórczości znanego opata. Pierwszy, obejmujący kluczowe dla tego myśliciela opracowania, takie jak słynna broszura "Co to jest stan trzeci" czy równie ważny, choć mniej znany "Esej o przywilejach" to teksty sprzed wybuchu Rewolucji, które w swoim całokształcie tworzą "doktrynę polityczną Rewolucji" ${ }^{1}$. Dla odmiany szkic Du jury constitutionnaire, wespół z innymi dziełami, które tworzył samodzielnie bądź współtworzył Sieyèes, jak chociażby Deklaracja Praw Człowieka i Obywatela

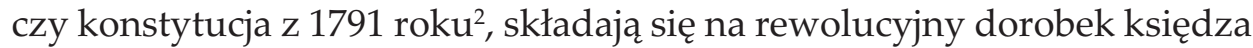
Sieyèsa i erygują tzw. „doktrynę konstytucyjną Rewolucji”, w której swój niebagatelny udział miał właśnie Emmanuel-Joseph Sieyès. Stąd nie przypadkowo jest on nazywany "ojcem konstytucjonalizmu”, „pierwszym francuskim konstytucjonalistą", "protoplastą myśli konstytucyjnej” albo „patronem” francuskich (i nie tylko zresztą) konstytucjonalistów ${ }^{3}$. Rozrzut zainteresowań księdza Sieyèsa, waga poruszanych przez niego spraw i wreszcie rezonansowość pomysłów są rzeczywiście nie do przecenienia. Atencja do twórczości opata nie jest zresztą produktem jedynie współczesności. Już Mirabeau komentując wpływ opata na rozwój doktryny ustrojowej i jego osobiste zaangażowanie w prace konstytucyjne $\mathrm{z}$ roku

\footnotetext{
${ }^{1}$ J. Touchard, Histoire des idées politiques, Paris 1959, t. II, s. 456.

2 Ale też i inne opracowania jak np.: Représentation et élections, Projet de Constitution hyopothétique oraz Préliminaire de la constitution française. Reconnaissance et exposition raisonnée des droits de l'homme et du citoyen.

${ }^{3}$ Por. M. Gauchet, La Révolution des pouvoirs. La souveraineté, le peuple et la représentation (1789-1799), Paris 1995, s. 82 i nast.
} 
1791, stwierdził wprost, iż „cisza obywatela Sieyèsa byłaby publicznym nieszczęściem"4 . Jego poglądy, dzięki oryginalności, nowoczesności i intelektualnemu rozmachowi oddziaływały nie tylko na akty ustrojowe doby Rewolucji, ale też na wszystkie późniejsze pomysły i koncepcje ustrojowe, a wielu kolejnych myślicieli grawitujących w okolicach prawa konstytucyjnego - by wspomnieć choćby Benjamina Constanta - uznawało swoje pokrewieństwo z Sieyèsem ${ }^{5}$. Nawet jeśli niektóre z tych poglądów dzisiaj przyblakły, jeśli obecnie inaczej je się interpretuje i jeśli ogląda je się pod zupełnie innym kątem, to faktem pozostaje, że ich najbardziej rudymentarny sens jest autorstwa Sieyèsa. Emmanuel-Joseph Sieyès stworzył wszak kapitał pojęć, które ciągle są obecne w prawie konstytucyjnym. Jak trafnie zauważył Pasquale Pasquino, kluczowe dla doktryny prawa konstytucyjnego pojęcia to pojęcia, jeśli nawet nie wprost sformułowane przez E.-J. Sieyèsa to takie, których znaczenie - choćby w elementarnym stopniu - nadał właśnie Sieyès. To jego zasługą jest przecież wprowadzenie do słownika dyskutowanych kwestii prawno-politycznych takich najbardziej podstawowych pojęć, jak „władza ustojodawcza” (pouvoir constituant); "rząd ograniczony" (gouvernement limité); "suwerenność narodowa" (souveraineté populaire) czy właśnie "sąd konstytucyjny” (jury constitutionnaire $)^{6}$.

Szczególną uwagę warto poświęcić opracowaniu poświęconemu właśnie sądowi konstytucyjnemu. Zostało ono opracowane i przedstawione przez Sieyèsa 18 Thermidora roku III, jako tezy projektu stosownej ustawy przedłożonej pod obrady Konwentu. Od razu należy też powiedzieć, że zgłoszony projekt nie został ostatecznie rozpatrzony i nie doszedł do skutku, pozostając jednak do dziś pomnikiem myśli Sieyèsa, a zarazem dowodem na to, że również pomysł na sądownictwo konstytucyjne ma swój rodowód francuski. Warto to szczególnie podkreślić, gdyż - jak wiadomo - Francję postrzega się dość standardowo jako wręcz modelową opozycję przeciwko jakimikolwiek pozaparlamentarnym formom kontroli konstytucyjności prawa. Kontrola ta nie została bowiem ustanowiona ani w czasach III Republiki , ani później, i dopiero w roku 1958

${ }^{4}$ M. Prélot, Histoire des idées polituques, Paris 1961, s. 421.

${ }^{5}$ Por. E. Hofmann, N. King, Les lettres de Benjamin Constant à Sieyès, „Annales Benjamin Constant" 1983, nr 3, s. 89 i nast.

${ }^{6}$ P. Pasquino, Sieyès et l'invention de la constitution en France, Paris 1998, s. 9, 10.

7 Choć w tym okresie kwestia ustanowienia sądowej kontroli konstytucyjności prawa, szczególnie w wariancie amerykańskiego jej modelu, była we Francji często i poważnie dyskutowana. Szerzej na ten temat zob. L. Jaume, Le contrôle de constitutionnalité de la loi a-t-il un sens pour la doctrine française de la Révolution et des premières années du XXe siècle?, [w:] 
wprowadzono do krwioobiegu instytucjonalnego V Republiki Radę Konstytucyjną, która jednak od samego początku wyraźnie "odstawała" od klasycznego już, Kelsenowskiego sądu konstytucyjnego i oceniana była jako swoiste rozwiązanie połowiczne będące następstwem ewidentnej niechęci Francuzów do sądownictwa konstytucyjnego, a zarazem uznania tego sądownictwa za pewien oczywisty już wymóg demokracji. Opór Francuzów przeciwko właściwemu sądownictwu konstytucyjnemu był generowany wieloma czynnikami, w tym także - paradoksalnie - myślą doby Rewolucji, która na piedestał pojęć konstytucyjnych wprowadziła pojęcie ustawy ${ }^{8}$ i woli powszechnej, z którą - jak sądzono - nie da się pogodzić efektywnej, pozaparlamentarnej kontroli konstytucyjności prawa ${ }^{9}$ ani w jej wariancie amerykańskim, ani europejskim (Kelsenowskim). Kiedy zaś ustanowiono Radę Konstytucyjną jej zaczynem była myśl zdecydowanie antyparlamentarna, która w dziejach konstytucjonalizmu francuskiego zderzała się z myślą, puentowaną jako afirmacja parlamentu ${ }^{10}$. Stąd też ostatecznie stworzony mechanizm kontroli konstytucyjności odstawał od tego, co było już znanym, uznanym i akceptowanym dorobkiem w zakresie kontroli konstytucyjności prawa. Myślą przewodnią utworzenia Rady Konstytucyjnej były bowiem jej antyparlamentarne uprawnienia, a sama kontrola konstytucyjności produktem raczej ubocznym i drugorzędnym wobec potrzeby ograniczenia władzy parlamentu (oryginalnym sensem istnienia Rady Konstytucyjnej było wszakże pilnowanie przez nią rozłączności materii zastrzeżonych dla parlamentu, przyjmującego prawo $\mathrm{w}$ formie ustawy i dla tzw. władzy reglamentacyjnej rządu). W rezultacie, dopiero po jakimś czasie kontrolę konstytucyjności prawa oderwano od jej jakoby atawistycznie wręcz antyparlamentarnego charakteru i pogodzono się $\mathrm{z}$ tym, że nie zawsze i niekoniecznie musi ona godzić w prerogatywy parlamentu, co - powracając do dyskusji wywołanej tezami

D. Chagnollaud (red.), Aux origines du contrôle de constitutionnalité XVIII ${ }^{-} X X^{e}$ siècle, Paris 2003, s. 17 i nast.

${ }^{8}$ Zwłaszcza afirmacja dl ustawy powodowała, że samą myśl o kontroli konstytucyjności uznawano za nie do pogodzenia ze szczególną, niemalże świętą rolą ustawy, będącą wyrazem woli suwerennego narodu. Szerzej na ten temat zob. R. Denois de Saint Marc, Histoire de la loi, Toulouse 2008, s. 43 i nast.

${ }^{9}$ Czego dowodziły najlepiej losy propozycji zgłoszonej przez Emmanuela-Josepha Sieyèsa, ostatecznie odrzuconej, gdyż postrzeganej jako godzącej w fundamentalne wartości i zasady Rewolucji.

10 Zauważa się, że dzieje ustroju Francji zawiera się między dwoma biegunowymi pomysłami, tj. właśnie afirmacją (éminente) parlamentu i parlamentaryzmu oraz - z drugiej strony - negacją i dewaluacją idei parlamentu i parlamentaryzmu (secondaire). Por. P. Blachèr, Le parlement en France, Paris 2012, s. 11. 
Sieyèsa - było zasadniczym powodem odrzucenia projektu ustawy o sądzie konstytucyjnym (jak się bowiem okazało myślą zdecydowanie silniejszą i ważniejsza, będącą pokłosiem Rewolucji, było uznanie parlamentu, jako przedstawiciela narodu, za organ bezkonkurencyjny i pod każdym względem priorytetowy ${ }^{11}$ ). Dopiero więc od jakiegoś czasu obserwuje się powolny proces „usądowienia” Rady, a krokiem milowym dla tego procesu były reformy konstytucyjne z 2008 roku' ${ }^{12}$, które istotnie zbliżyły francuską Radę Konstytucyjną do Kelsenowskiego sądu konstytucyjnego ${ }^{13}$.

Pomysł Emmanuela-Josepha Sieyèsa na jury constitutionnaire był wielce osobliwy, a zarazem niezwykle konsekwentny i logiczny, tworząc wespół z innymi jego konstrukcjami myślowymi (takimi jak: suwerenność narodu, ranga i pozycja ustawy, przedstawicielstwo polityczne, parlament jako nowoczesne Assemblée nationale, pojęcie aktu konstytucyjnego, fundamentalne prawa i wolności jednostki czy w końcu wola powszechna) pewną wspólną i spójną całość. Paradoksalnie, kontrola konstytucyjności prawa była dla opata wtórna wobec zasadniczego jego projektu ustrojowego jakim była pouvoir constituant. Sąd konstytucyjny był bowiem przez niego pomyślany jako gwarant aktu konstytucyjnego ${ }^{14} \mathrm{~W}$ pełnym tego słowa znaczeniu, tzn. zarówno na etapie stosowania prawa (jako właściwy sąd konstytucyjny), jak i na etapie tworzenia prawa (zmiany konstytucji). Wydaje się przy tym, że pierwszego rodzaju aktywność sądu konstytucyjnego (tzn. na poziomie oceny konstytucyjności) była wtórna, a zrazem wyjściowa dla zasadniczej jego roli ustrojowej jaką miała być ewentualna inspiracja działań legislacyjnych zmierzających do zmiany aktu konstytucyjnego. Dzięki temu jury constitutionnaire stawał się autentycznym gwarantem (conservateur) konstytucji. Chronił ją bowiem, w jakimś sensie, dwojako, tzn. poprzez ocenę aktów podkonstytucyjnych oraz - poprzez -

${ }^{11}$ Co swoją drogą także było owocem myśli Sieyèsa. Stąd nota bene, zarzuca się czasami opatowi eklektyzm pomysłów i to, że były one bardzo rozmaite, niekoniecznie spójne i logiczne. Niemniej eklektyzmy pomysłów opata dzisiaj są wyraźnie łagodzone, a krytyka jego poglądów o wile łagodniejsza niż kiedyś. Por. J. Szymanek, Emmanuel-Joseph Sieyès i jego doktryna konstytucyjna, [w:] Czym jest stan trzeci? Esej o przywilejach, E.-J. Sieyès, tłum. M. Jarosz, Warszawa 2016, s. 23 i nast.

${ }^{12}$ Choć już wcześniej, jak się wskazuje, bo od lat 80-tych XX wieku usądowienie to dało się zaobserwować zwłaszcza uwzględniając dorobek orzecznicy Rady. Zob. J. Meunier, Les décisions du Conseil constitutionnel et la jeu politique, „Pouvoirs” 2003, nr 105, s. 29 i nast.

${ }^{13}$ Szerzej na ten temat zob. J. Massot, Le question prioritaire de constitutionnalité, [w:] J.-P. Camby, P. Fraisseix, J. Gicquel (red.), La révision de 2008. Une nouvelle Constitution?, Paris 2011, s. 321 i nast.

${ }^{14}$ Szeroko zresztą rozumianego, jako baza dla całej hierarchii norm prawnych. Por. M. Troper, Sieyès et la hierarchie des normes, [w:] P.-Y. Quiviger, V. Denis, J. Salem (red.), Figures de Sieyès, Paris 2008, s. 25 i nast. 
przedkładanie stosownych uwag i propozycji zamiany konstytucji po to by, jak mówił sam Sieyès, uczynić ją „,doskonałą” (perfectionner). Co więcej, dla Sieyèsa to właśnie drugi sposób zaangażowania sądu konstytucyjnego był sednem jego działalności, podczas gdy pierwszy jedynie środkiem osiągniecia celu zasadniczego (propozycje zmian konstytucji miałby być bowiem formułowane à propos orzecznictwa sądu w sprawach konstytucyjnych, będąc $w$ pewnym sensie, jego okresowym podsumowaniem i wychodzeniem naprzeciw ujawniającym się problemom). Sąd konstytucyjny był w efekcie dla Sieyèsa sui generis organem władzy ustrojodawczej, która to władza stanowiła oś myśli ustrojowej opata ${ }^{15}$. Dzięki temu pomysłowi Sieyèsowski sąd konstytucyjny przekraczał Rubikon organu orzecznictwa konstytucyjnego, zarówno w wydaniu amerykańskiego judicial review, jak i europejskiego, dzisiejszego cour constitutionnele ${ }^{16}$ i nabierał cech szczególnych, stając się - jak mówił sam autor - rzeczywistym "depozytariuszem gwarancji aktu konstytucyjnego" (dépositaire conservateur de l'acte constitutionnel), którego rola była dużo bardziej ambitna aniżeli sama ocena konstytucyjności weryfikowanych norm. Ideą przewodnią dla Sieyèsa było wszakże uczynienie sądu konstytucyjnego organem pilnującym rangi i prestiżu konstytucji, która była dla niego wyrazem swoistego kontraktu ustrojowego ${ }^{17}$. Stąd w swojej propozycji uwzględnił on wszystkie elementy czy też poziomy właściwego dekodowania tekstu konstytucji i czynienia go doskonałym. W efekcie, gwarancje aktu konstytucyjnego były obustronnie niejako zamknięte, tzn. poprzez odczytywanie jego tekstu w dodrze działalności orzeczniczej w stosunku do aktów podkonstytucyjnych, jak i w drodze formułowania postulatów de lege ferenda. Co więcej, na etapie zwykłej działalności orzeczniczej Sieyès adresuje do sądu konstytucyjnego wyraźny postulat interpretowania prawa $\mathrm{w}$ duchu konstytucji oraz Deklaracji Praw Człowieka i Obywatela (przy pisaniu której miał swój niebagatelny udział), tak aby uzyskać efekt pierwszorzędny w postaci uczynniania obu tych aktów aktami możliwie najbardziej spełnionymi i doskonałymi (będąc dzięki temu jednym z pierwszych którzy tak wyraźnie opowiadali się za pierwszeństwem konstytucji i aktów względem niej równorzędnych w całym hierarchicznie zbudowanym systemie źródeł prawa). Zarazem Sieyès, co niezwykle ważne, akcentuje potrzebę nie tylko kontroli abstrakcyjnej (uwolnionej od okoliczności stosowania aktu prawnego poddanego procedurze kontroli konstytucyjno-

\footnotetext{
15 Por. P. Pasquino, Sieyès et l'invention..., s. 15 i nast.

${ }^{16}$ Szerzej na ten temat zob. F. Hamon, C. Winer, La justice constitutionnelle en France et à l'étranger, Paris 2011, s. 24 i nast.

17 Por. P. Pasquino, Sieyès et l'invention..., s. 129 i nast.
} 
ści) ale także wprowadza kontrolę konkretną proponując rozwiązanie, które stanowi pierwowzór współczesnego pytania prawnego ${ }^{18}$. Według pomysłu opata każdy sąd powszechny (tribunal) mógł bowiem wystąpić do sądu konstytucyjnego z pytaniem, które warunkowało wydanie orzeczenia w konkretnej sprawie zawisłej przed sądem. Patrząc zaś na dzisiejsze problemy, jakie ewokuje sądownictwo konstytucyjne, wielce symptomatycznie ale też i ze wszech miar racjonalnie wygląda propozycja Sieyès zawarta w ostatniej przedłożonej przez niego tezie uwag o sądzie konstytucyjnym, jaką jest zakaz wypowiadania się przez jury constitutionnaire we własnych sprawach (ne peut rendre aucun arrêt du propre mouvement).

Pomysł na jury constitutionnaire, jak wiadomo, nie zyskał akceptacji. Pozostaje on jednak istotnym świadectwem myśli Emmanuela-Josepha Sieyèsa, który dzięki m.in. tej propozycji postrzegany jest nieprzypadkowo jako prawdziwy prekursor nowożytnego konstytucjonalizmu. Pojęcia, które albo stworzył, albo przynamniej objaśnił bądź nadał im inny, nowy sens opat Sieyès tworzą wszak obecnie kanon wartości i zasad ustrojowych kojarzonych z demokratycznym konstytucjonalizmem. Jedną z nich jest bez wątpienia pozaparlamentarna kontrola konstytucyjności prawa, która jak się okazuje, ma także swój francuski prototyp.

$* * *$

\section{O sądzie konstytucyjnym ${ }^{19}$}

\section{Art. I}

Istnieć będzie depozytariusz zachowujący gwarancje $\mathrm{e}^{20}$ aktu konstytucyjnego pod nazwą sądu konstytucyjnego ${ }^{21}$.

${ }^{18}$ Uznaje on bowiem, że akt konstytucyjny należy możliwie dalece obudować zaporami i gwarancjami, po to by uniemożliwić jego wszelkiego rodzaju naruszenia. Por. M. Fioravanti, Sieyès et le jury constitutionnel: perspectives historico-juridiques, "Annales Historiques de la Révolution Française" 2007, nr 349, s. 87 i nast.

${ }^{19}$ Du jury constitutionnaire - tekst projektu ustawy przygotowanego i zaprezentowanego przez J.-E, Sieyesa podczas obrad Konwencji w dniu 18 Thermidora roku III. Niniejsze tłumaczenie oparte na tekście zamieszczonym w: K.-E. Sieyes, Euvres de Sieyes, Paris 1990, powtórzonym w: P. Pasquino, Sieyes et l'invention de la Constitution en France, Paris 1998, s. 193-196.

${ }^{20} \mathrm{~W}$ oryginale: dépositaire conservateur.

${ }^{21} \mathrm{~W}$ oryginale: jury constitutionnaire. 


\section{Art. II}

Złożony on będzie ze stu ośmiu członków, których skład odnawiany będzie corocznie w wielkości jednej trzeciej, w tym samym czasie co Ciała Ustawodawczego.

\section{Art. III}

Wyboru jednej trzeciej sądu konstytucyjnego, czyli trzydziestu sześciu członków, będzie dokonywać sam sąd konstytucyjny spośród dwustu pięćdziesięciu członków, którzy w tym samym, rocznym okresie opuszczać będą skład Ciała Ustawodawczego.

\section{Art. IV}

Pierwszy wybór składu sądu konstytucyjnego odbędzie się w głosowaniu tajnym przez Konwencję w taki sposób, że po jednej trzeciej członków sądu wybranych będzie ze Zgromadzenia Narodowego, zwanego konstytuantą ${ }^{22}$, po jednej trzeciej ze Zgromadzenia Ustawodawczego i po jednej trzeciej z Konwencji.

\section{Art. V}

Posiedzenia ${ }^{23}$ sądu konstytucyjnego będą niejawne ${ }^{24}$.

\section{Art. VI}

Sąd konstytucyjny zabierać będzie głos w sprawach naruszeńn ${ }^{25}$ lub nadużyć konstytucji ${ }^{26}$, które stoją w sprzeczności z aktami:

\footnotetext{
${ }^{22} \mathrm{~W}$ oryginale: dite constituante.

${ }^{23}$ W oryginale: les séances.

${ }^{24}$ W oryginale: ne seront point publiques.

${ }^{25}$ W oryginale: violations.

${ }^{26} \mathrm{~W}$ oryginale: atteintes faites.
} 
Bądź to ${ }^{27}$ Rady Starszych,

Bądź to Rady Pięciuset,

Bądź to zgromadzeń wyborczych,

Bądź to zgromadzeń komunalnych,

Bądź to trybunału kasacyjnego,

Wówczas, kiedy te sprzeczności będą mu wskazane

Bądź to przez Radę Starszych,

Bądź to przez Radę Pięciuset

Bądź przez pojedynczych obywateli.

Będzie on również wypowiadał $\operatorname{się}^{28} \mathrm{w}$ sprawach naruszeń, które będą mogły być popełnione przez mniejszość wobec większości jednego lub drugiego spośród wskazanych ciał.

\section{Art. VII}

Decyzje sądu konstytucyjnego nosić będą nazwę wyroków ${ }^{29}$.

\section{Art. VIII}

Akty uznane wyrokiem sądu za niekonstytucyjne będą nieważne i traktowane jako niebyłe ${ }^{30}$.

\section{Art. IX}

Jeśli zdarzy się tak, że akty uznane za niekonstytucyjne będą aktami odpowiedzialnymi bądź powiązanymi z nimi ${ }^{31}$ sąd może, przed lub po powzięciu wyroku o ich niekonstytucyjności, przekazać oskarżenie odpowiedniemu trybunałowi z nakazem kontynuacji sprawy.

${ }^{27}$ W oryginale: soit $d u$.

${ }^{28}$ W oryginale: dénonciation.

${ }^{29}$ W oryginale: d'arrêt.

${ }^{30}$ W oryginale: $n u l s$ et comme non avenus.

${ }^{31}$ W oryginale: actes responsables ou mêlés d'actes responsables. Chodzi tu o akty, na podstawie których toczone były postępowania z tytułu odpowiedzialności karnej. 


\section{Art. X}

Sąd konstytucyjny wydając swoje wyroki będzie zajmował stanowisko ${ }^{32}$, które uzna za właściwe, kierując się zasadą aby akt konstytucyjny oraz Deklarację Praw Człowieka i Obywatela uczynić aktami jak najbardziej doskonałymi ${ }^{33}$.

Zdanie większości, kiedy będzie już sformułowane, zapisane zostanie w rejestrze sądu.

\section{Art. XI}

W każdym roku dziesiątym i jego wielokrotności ${ }^{34}$, począwszy od roku 1800, to jest ósmego roku Republiki i dwunastego roku od Rewolucji, sąd konstytucyjny będzie weryfikować swoje wyroki spisane w rejestrze.

Na tej podstawie sąd konstytucyjny stworzy zeszyt propozycji ${ }^{35}$, dzięki którym będzie można poprawić36 akt konstytucyjny i uczynić go jeszcze doskonalszym.

Zeszyt propozycji będzie oficjalnie komunikowany Radzie Starszych i Radzie Pięciuset, po to by propozycje te zyskały stosowną uwagę ${ }^{37}$.

Przedłożenie zeszytu propozycji do wglądu stosownym organom będzie mieć miejsce co najmniej na trzy miesiące przed rozpoczęciem rocznych posiedzeń zgromadzeń komunalnych.

\section{Art. XII}

Zgromadzenia początkowe ${ }^{38}$, po lekturze zeszytu propozycji, opowiadać się będą za lub przeciw ${ }^{39}$, w sprawie tego czy zamierzają przekazać go Radzie Starszych w celu ukonstytuowania ${ }^{40}$.

\footnotetext{
${ }^{32}$ W oryginale: s'occupera habituellement.

${ }^{33} \mathrm{~W}$ oryginale: perfectionner.

${ }^{34} \mathrm{~W}$ oryginale: de chaque dixième année.

${ }^{35} \mathrm{~W}$ oryginale: cahier de propositions.

${ }^{36}$ W oryginale: améliorer.

${ }^{37} \mathrm{~W}$ oryginale: plus grande publicité.

${ }^{38}$ W oryginale: Les assemblées primaires.

${ }^{39} \mathrm{~W}$ oryginale oui ou non.

${ }^{40} \mathrm{~W}$ oryginale: le pouvoir d'y statuer.
} 
Jeśli większość spośród zgromadzeń początkowych wypowie się przeciw, zeszyt uznany będzie za niebyły ${ }^{41}$, a zawarte $\mathrm{w}$ nim propozycje nie będę rozpatrywane $\mathrm{w}$ czasie kolejnego dziesięciolecia.

Jeśli natomiast większość ze zgromadzeń początkowych opowie się za, władza konstytucyjna ${ }^{42}$ delegowana będzie do Rady Starszych, by ta mogła zatwierdzić ostatecznie propozycje, które nie będą mogły, w czasie ich przyjmowania, zastać zmienione ani zastąpione innymi ${ }^{43}$.

\section{Art. XIII}

Posiedzenia, gdy Rada Starszych wykonywać będzie władzę konstytucyjną ${ }^{44}$ będą wyjątkiem ${ }^{45}$.

Posiedzenia takie nie będą mogły przekraczać liczby dwunastu w ogó$1 e^{46}$ ani dwóch na dekadę ${ }^{47}$.

Dla posiedzeń władzy konstytucyjnej istnieć będzie oddzielny proces spisywania rejestru, który będzie, na sam koniec, uroczyście złożony w archiwach sądu konstytucyjnego.

\section{Art. XIV}

Każdego roku co najmniej dziesięciu członków sądu konstytucyjnego, wybranych losowo, sformułuje sąd sprawiedliwości ${ }^{48}$.

Sąd ${ }^{49}$ ten, oprócz dwóch innych przyznanych mu wcześniej właściwości, wypowiadać się będzie na temat oficjalnych pytań, które będą mu zadawane przez sądy powszechne ${ }^{50} \mathrm{~W}$ wyniku sprawowanego przez nie wymiaru sprawiedliwości, wówczas kiedy nie będą one w stanie ocenić winy w prawie pozytywnym albo kiedy przepisy przez nie stosowane nie

\footnotetext{
${ }^{41} \mathrm{~W}$ oryginale: sera regardé comme non avenu.

${ }^{42} \mathrm{~W}$ oryginale: le pouvoir constituant.

${ }^{43}$ W oryginale: sens qu'il puisse nie les amender ni en substituer d'autres.

${ }^{44}$ W oryginale: exercera le pouvoir constituant.

${ }^{45}$ W oryginale: exclusivement affectées.

${ }^{46} \mathrm{~W}$ oryginale: douze en tout.

${ }^{47} \mathrm{~W}$ oryginale: deux par décade.

${ }^{48}$ W oryginale: jury d'équité naturelle.

${ }^{49}$ W oryginale: Cette section.

${ }^{50} \mathrm{~W}$ oryginale: divers tribunaux.
} 
mogą mogły być zastosowane do rozstrzygnięcia danej sprawy ze względu na swoją zawiłość lub innego rodzaju problematycznośćc1.

\section{Art. XV}

Wyroki $^{52}$ sądu sprawiedliwości będą wykonywane przez sąd, który sformułował oficjalne pytanie względnie przez każdy inny, wskazany przez sąd konstytucyjny.

\section{Art. XVI}

Wszystkie orzeczenia sądu sprawiedliwości będą oficjalnie komunikowane w miesiącu, w którym zbierać się będzie Rada Pięciuset.

\section{Art. XVII}

Sąd konstytucyjny nie będzie uprawniony do wypowiadania się we własnych sprawach ${ }^{53}$.

Wstęp i tłumaczenie: Jarosław Szymanek*

${ }^{51}$ W oryginale: ou ne pouvoir juger que contre leut conscience, d'après le texte seul de la loi.

${ }^{52} \mathrm{~W}$ oryginale: d'arrêts.

${ }^{53}$ W oryginale: ne peut rendre aucun arrêt du propre mouvement.

* Prof. UW, dr hab.; Instytut Nauk Politycznych Uniwersytetu Warszawskiego; jaroslawszymanek@o2.pl. 